\title{
Protection of Construction Workers with Personal Protective Equipment
}

\author{
$1^{\text {st }}$ Muntiyono \\ Sekolah Tinggi Teknologi Mandala \\ Bandung, Indonesia \\ muntibdg@yahoo.com \\ $4^{\text {th }}$ Andrew Ghea Mahardika \\ Sekolah Tinggi Teknologi Mandala \\ Bandung, Indonesia
}

\author{
$2^{\text {nd }}$ Samun Haris \\ Sekolah Tinggi Teknologi Mandala \\ Bandung, Indonesia \\ $5^{\text {th }}$ Hetty Fadriani \\ Sekolah Tinggi Teknologi Mandala \\ Bandung, Indonesia
}

\author{
$3^{\text {rd }}$ Budi Nuryono \\ Sekolah Tinggi Teknologi Mandala \\ Bandung, Indonesia \\ $6^{\text {th }}$ Iman Hidayat \\ Sekolah Tinggi Teknologi Mandala \\ Bandung, Indonesia
}

\begin{abstract}
Construction accidents, such as the fall of cranes in Palembang, and others from 2017 to 2019 have increased, Statistics of work accidents in the field of instruction reached $32 \%$. Construction work accidents have an impact on their work so they need to protect workers with Personal Protective Equipment (PPE). Service providers must establish a Construction Safety Unit and require the use of PPE so that the worker meets the construction, safety, health, and sustainability standards of construction. Implementation of implementation by construction management consultancy, Construction Consultancy supervision and Construction Work with due regard to construction engineering safety and others. In the implementation of construction projects, many construction workers do not pay attention to themselves related to their safety and health. This study tries to find a problem by using a comparison method, by comparing workers who are equipped with PPE and who do not use PPE in various places. Many construction workers are reluctant to use PPE even for their safety, with the Minister of PUPR and Minister of Manpower Regulations that workers must use PPE. Service Providers form the Construction Safety Unit (UKK). Construction workers in carrying out their duties must use PPE.
\end{abstract}

Keywords-Construction, Workers, Protective, Equipment

\section{INTRODUCTION}

Construction Safety is all engineering activities to support Construction Work in realizing the fulfillment of security, safety, health and sustainability standards that guarantee construction engineering safety, workforce safety and health, public safety and the environment under the Republic of Indonesia Law concerning Work Safety and Employment. [1]

Regulations on the Implementation of the Occupational Safety and Health Management System and also The Construction Safety Management System, hereinafter referred to as SMKK, is part of the management system for the implementation of Construction Work to ensure the realization of Construction Safety. [2][3]

Construction accidents, such as the fall of cranes in Palembang, and others from 2017 to 2019 have increased, Statistics of work accidents in the field of instruction reached $32 \%$. Construction work accidents have an impact on their work so they need to protect workers with Personal Protective Equipment (PPE). [4]

The development of construction activities today is increasing rapidly with the hope that economic growth will improve by the expected goals, however, accidents in the field of construction have also increased from 2017 to the present, such as:[5]

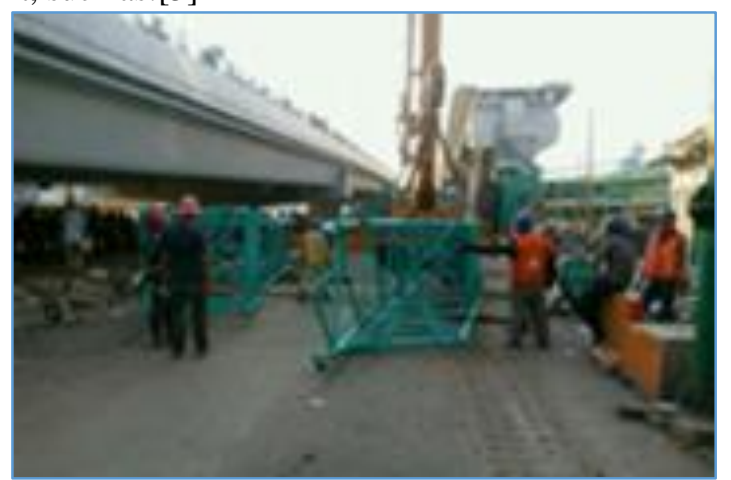

Fig. 1. The fall of the crane The fall of the crane in Palembang, Major Construction Accidents: In August the fall of Crane (Light Rail Transit) in Palembang

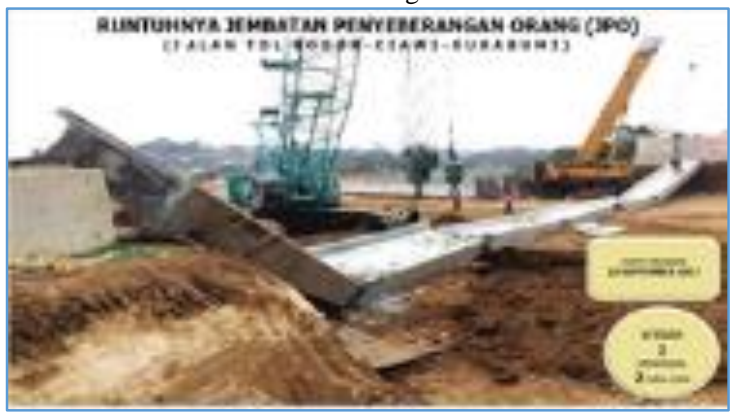

Fig. 2. The collapse of the People Crossing Bridge, In September the collapse of the People Crossing Bridge (JPO) on the Bogor-CiawiSukabumi Toll Road the collapse of the pedestrian bridge on the Bocimi toll road 


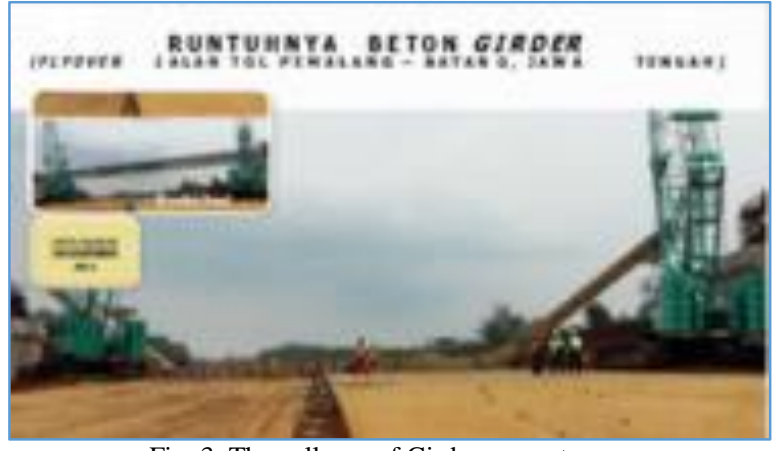

Fig. 3. The collapse of Girder concrete

The collapse of Girder concrete on Pemalang and other toll roads Construction accidents from 2017 to 2019 have increased rather than decreased, so that in February 2018 the Minister of Public Works and Public Housing (PUPR) suspended some vital construction work for a while and in time resumed.

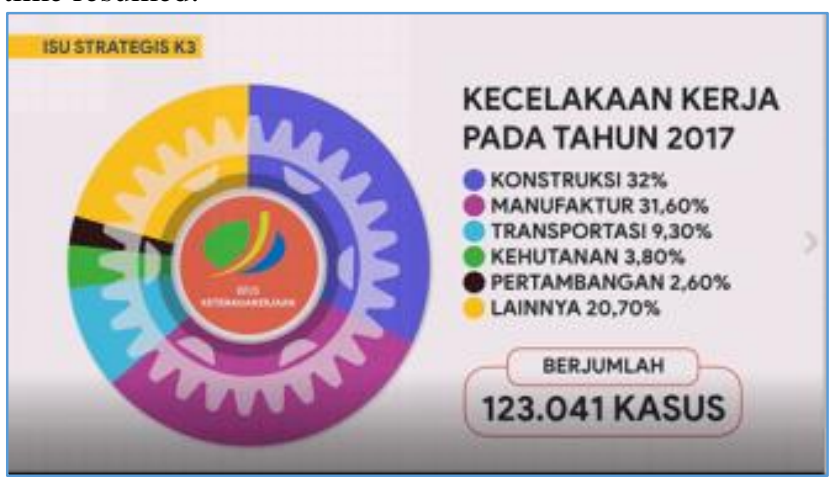

Fig. 4. The strategic issue of work accidents in 2017

Data from work accidents in Indonesia in the strategic issue of work accidents in 2017, construction work accidents reached $32 \%$.

Where an accident is a condition or event that is unplanned, unwanted, and not previously thought, the accident can occur at any time and has a detrimental nature to human injury, damage to construction machinery or equipment, even to damage to company assets/property, the late completion of construction work due to the cessation of the construction production process, and the possibility of negative impacts on the overall development. With the regulation of the Minister of PUPR, it is anticipated that related to Construction Safety when compiling tender documents the provider is required to issue a Construction Safety Plan which includes Personal Protective Equipment for construction workers. [6]

\section{ISSUES}

From the results of interviews in several development projects in Bandung, construction workers generally do not want to use PPE that seems to disturb or add to their burden, from various levels of accident construction workers must be willing to use PPE provided by the Service Provider and the Service Provider is obliged to form a Unit Construction Safety to regulate the management of work safety in the project so that workers meet the safety, safety, health and sustainability of construction standards. The implementation of Construction Safety implementation is carried out by the management of construction management consultancy, Construction Consultancy supervision and Construction Work with due regard to the safety of construction engineering and others contained in the relevant regulations. [7]

Minister of PUPR Decree number 21 of 2019 regarding Construction Safety Management System (SMKK) which is also mandated by the Law of the Republic of Indonesia number 2 of 2017 concerning Construction Services to realize the orderly implementation of Construction Services by the standards of safety, safety, health, sustainability and meet the aspects of construction and supervision of construction safety nationally. In its implementation, the service provider must establish a Construction Safety Unit (UKK) accompanied by a Construction Safety and Health Expert (K3) or Construction Safety Officer. [8]

Construction Safety Risks are determined by Service Users with the following criteria:

- Minor Construction Safety Risks;

- Medium Construction Safety Risks; and

- Large Construction Safety Risks.

The cost of implementing the SMKK must be included in the quantity and price list with the amount of the cost by the needs based on the control in the Construction Safety Plan (RKK). Guidance and Supervision are carried out by the Minister at the Central level, the Governor at the Provincial level and the Regent / Mayor at the Regency / City level. [9]-[11]

\section{METHOD}

\section{A. Personal Protective Equipment (PPE) includes: [12]}

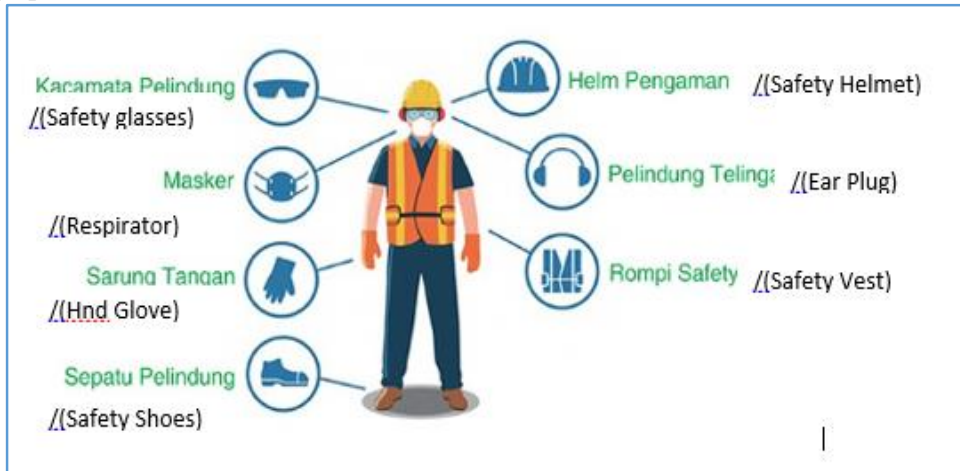

Fig. 5. The placement of personal protective equipment 
B. Research with interviews from various projects carried out on construction workers in Bandung and by using a comparison method, by comparing workers who are equipped with PPE and who do not use PPE in various places and their losses are as follows: [13][14]

Table 1. comparison table that uses PPE and which does not use

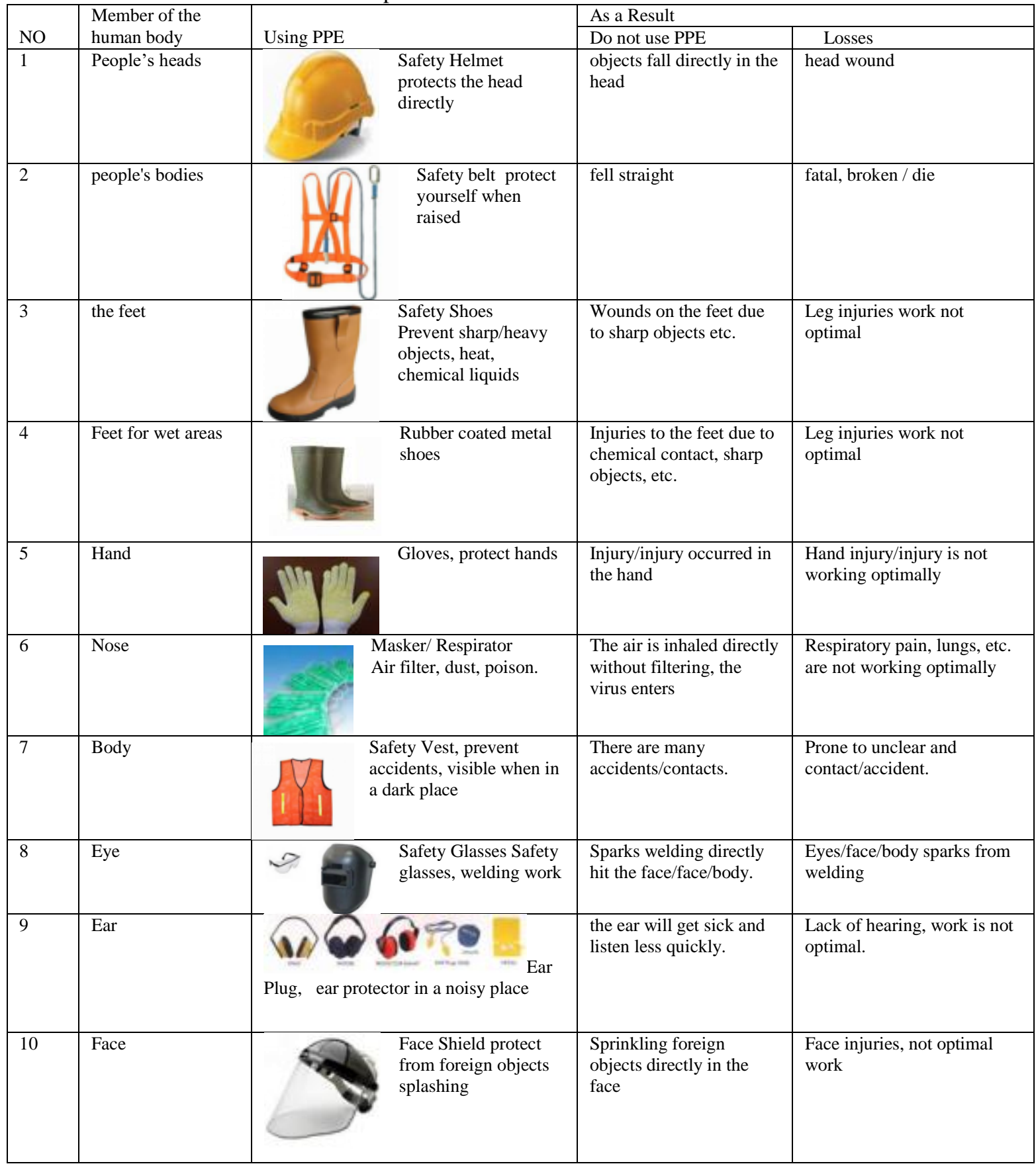

\section{Coaching:}

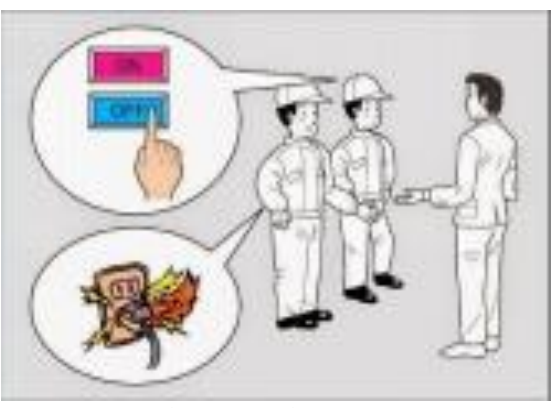

Fig. 6. Meeting 
The development of construction workers is carried out 10-15 minutes before carrying out activities. By reminding work procedures, the use of PPE and evacuation in case of fire, earthquake, and others.[15]

\section{CONCLUSION}

Safety Construction with accident rates close to zero is needed to obtain optimal work results, and is one aspect that needs to be considered by all parties involved, in addition to meeting production targets and reducing the negative impact/work accident on the environment and cannot be separated with the other. In reducing the accident rate, it must be a common desire for a goal that has a strategic role. By using Personal Protective Equipment, construction workers have minimized work accidents. This helps the strategic role. Balanced with guidance from the Construction Work Unit formed by the Service Provider which is the implementation of the provisions governed by the Minister of Public Works and Public Housing on the Construction Safety Management System and the Minister of Manpower of the Republic of Indonesia concerning manpower desiring no accident in a project will be implemented. Suggestions for continued use of PPE are to be periodically notified or socialized.

\section{REFERENCES}

11] Y. Mahendradhata et al., "The Republic of Indonesia health system review," 2017.

[2] I. Cruz and R. Huerta-Mercado, "Occupational Safety and Health in Peru," Ann. Glob. Heal., vol. 81, no. 4, pp. 568-575, 2015.

[3] Y. Latief, R. A. Machfudiyanto, R. Arifuddin, R. M. F. Setiawan, and Y. Yogiswara, "Study of evaluation OSH management system policy based on safety culture dimensions in construction project," in Journal of Physics: Conference Series, 2017, vol. 877, no. 1 , p. 12028.

[4] J. Izudi, V. Ninsiima, and J. B. Alege, "Use of personal protective equipment among building construction workers in Kampala,
Uganda," J. Environ. Public Health, vol. 2017, 2017.

[5] K. Mori and T. Takebayashi, "The introduction of an occupational health management system for solving issues in occupational health activities in Japan," Ind. Health, vol. 40, no. 2, pp. 167-174, 2002.

[6] M. Saefullah and F. Santiago, "Legal Protection of Mining Workers from The Perspective of Mining and Labor Law," in 2018 International Conference on Energy and Mining Law (ICEML 2018), 2018.

[7] B. L. Tanko and N. A. Anigbogu, "The use of personal protective equipment (PPE) on construction sites in Nigeria," in In: Laryea, S., Agyepong, SA, Leiringer, R. and Hughes, W.(Eds) Procs 4th West Africa Built Environment Research (WABER) Conference, 24-26 July 2012, Abuja, Nigeria, 2012, pp. 1341-1348.

[8] A. H. S. Chan, W. Y. Kwok, and V. G. Duffy, "Using AHP for determining priority in a safety management system," Ind. Manag. Data Syst., 2004.

[9] A. G. Mahardika, H. Fadriani, S. Afiyah, and G. D. Ramady, "Analysis of Time Acceleration Costs in Level Building Using Critical Path Method," in Journal of Physics: Conference Series, 2019, vol. 1424, no. 1, p. 12025.

[10] H. Fadriani and A. I. Syah, "Pengaruh Pedagang Kaki Lima Di Badan Jalan Terhadap Kecepatan Dan Kapasitas Jalan,” J. Online Sekol. Tinggi Teknol. Mandala, vol. 14, no. 1, pp. 1-7, 2019.

[11] G. D. Ramady and R. G. Wowiling, "Analisa Prediksi Laju Kendaraan Menggunakan Metode Linear Regresion Sebagai Indikator Tingkat Kemacetan," J. Online Sekol. Tinggi Teknol. Mandala, vol. 12, no. 2, pp. 22-28, 2017.

[12] K. PUPR, "Peraturan Menteri Pekerjaan Umum dan Perumahan Rakyat Nomor: 17," PRT/M/2018 tentang Perubahan atas Peraturan Menteri Pekerjaan Umum Nomor: 22 ..., 2008.

[13] S. Syarief, "reconstruction of legal sanctions on building failure in law no. 2 year 2017 on construction services based on the value of benefit," in The 3rd International Conference and Call for Paper, 2018, vol. 1, no. 1.

[14] C. Roelofs, L. Sprague-Martinez, M. Brunette, and L. Azaroff, "A qualitative investigation of Hispanic construction worker perspectives on factors impacting worksite safety and risk," Environ. Heal., vol. 10, no. 1, p. 84, 2011.

[15] M. U. N. TIYONO, "Perhitungan Tebal Lapis Perkerasan Lentur (Flexible Pavement) Pada Ruas Jalan Ring Road Ii Samarinda Dengan Metode Analisa Komponen," KURVA S J. Mhs., vol. 1, no. 2, pp. 884-894, 2014. 